\title{
Analisis Competitive Forces and Competitive Strategy pada Sistem Informasi "Zalora.co.id"
}

\author{
Fitria Ekarini \\ Pendidikan Teknik Elektronika dan Informatikation \\ Pascasarjana Universitas Negeri Yogyakarta \\ Email: ekka.rhiea@gmail.com
}

\begin{abstract}
ABSTRAK
Analisis Sistem Informasi Zalora.co.id ini bertujuan untuk mengetahui seberapa kuatnya strategi persaingan yang disiapkan oleh Zalora.co.id untuk menghadapi kuatnya persaingan bisnis dengan perusahaan yang bergerak di bidang yang sama. Sehingga dapat dilihat kelebihan dan kekurangan dari Sistem Informasi ini. Analisis Sistem Informasi ini menggunakan model analisis competitive forces and Competitive Strategy. Dan untuk mengatasi lima kekuatan kompetitif tersebut, perusahaan dapat menerapkan competitive strategies. Pada Zalora yang merupakan situs web belanja kebutuhan fashion yang menawarkan produk-produk dari berbagai brand termuka, baik lokal maupun internasional ini dapat dikatakan sebagai online shop yang siap untuk bersaing dengan para kompetitor di bidang yang sama. Kelemahan dari Sistem Informasi Zalora ini terdapat pada lemahnya Zalora dalam mengahadapi kekuatan Ancaman Kekuatan tawar pelanggan, Ancaman produk pengganti yang mungkin menangkap mangsa pasar, Ancaman industri pendatang baru. dan kelebihan dari Sistem Infomasi Zalora terletak pada kuatnya Zalora dalam menghadapi kekuatan Ancaman Persaingan dari pesaing dalam industri dan Ancaman Kekuatan tawar pemasok . dan juga kelebihan dari Sistem Informasi Zalora terletak pada Strategi Cost Leadership, Strategi Inovasi, dan Strategi Aliansi yang sudah ada dalam Sistem Infomasi ini.
\end{abstract}

Kata Kunci: Sistem Informasi, Competitive Forces, Competitive Strategy

\section{PENDAHULUAN}

Zalora adalah situs web belanja kebutuhan fashion yang menawarkan produkproduk dari berbagai brand termuka, baik lokal maupun internasional. Zalora Indonesia merupakan bagian dari ZALORA Group, yang didirikan pada akhir 2011 oleh Rocket Internet $\mathrm{GmbH}$, yang mencakup Grup retail fashion online terkemuka di Asia Pasifik The Iconic di Australia dan Selandia Baru. Situs belanja online ini merupakan salah satu cabang dari toko online terbesar di Eropa, Zalando. Di lingkup Asia namanya Zalora yang memiliki adik perusahaan di delapan negara, seperti Indonesia, Malaysia, Singapura, Vietnam, Taiwan, Hongkong, Thailand, dan Filipina.

Zalora sebagai online fashion destinasi terbesar di Asia Tenggara sehingga dengan penuh keyakinan bahwa bisnis e-commerce di tanah air akan berhasil. Karena akses ke daerah kecil masih kurang, dengan ada nya zalora semua orang punya akses. Perkembangannya di dukung oleh kerja sama tim Zalora dalam memasarkan web-store mereka. Diawali dari promosi secara online, seperti melalui Google, Facebook, Twitter, hingga kini ke media eletronik.

Zalora memiliki koleksi lebih dari 500 merek lokal, internasional dan designer, pelanggan dapat berbelanja online dengan pilihan produk fashion pria dan wanita mulai dari pakaian, sepatu, aksesoris dan produk kecantikan.Pelanggan Zalora dapat menikmati kemudahan 30 hari gratis pengembalian, Pengiriman Gratis*, Pengiriman Tercepat selama 1-3 hari kerja dan beberapa metode pembayaran termasuk COD (Cash On Delivery).

Zalora hadir sebagai online shop yang berkomitmen untuk memuaskan konsumen dengan menyediakan berbagai produk istimewa dan layanan yang memuaskan. Sebagaimana 
yang diinformasikan dalam official websitanya, Zalora selalu menambahkan model terbaru untuk melengkapi koleksi brand yang tersedia dan memaksimalkan perannya sebagai sumber tips-tips trendi dan fashion advice yang senantiasa membantu konsumen untuk berbelanja dengan penuh percaya diri. Dengan komitmen dan kemudahan akses di berbagai situsnya, Zalora hadir sebagai online shop yang menyediakan layanan terbaik demi konsumennya.

\section{METODE}

Metode yang digunakan dalam analisis Sistem Informasi "Zalora.co.id" ini adalah metode Competitive Forces and Competitive Strategy dari O'Brien dan Maracas yang dapat menjelaskan strategi kompetitif dan kekuatan kompetitif sehinga dapat diketahui kelebihan ataupun kekurangan dari Sistem Informasi tersebut.

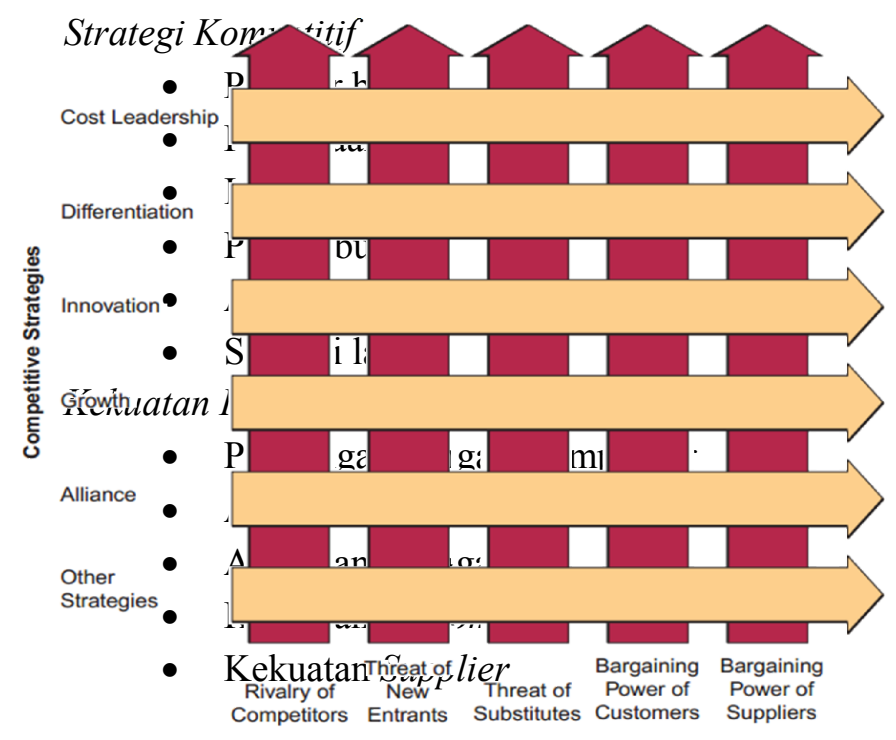

\section{HASIL DAN PEMB çompétififié Fồçces}

a. Lima Kekuatan Kompetitif

\section{(1) Persaingan dari pesaing dalam industri}

Ancaman ini adalah meningkatnya persaingan dari kompetitor. Salah satu contoh penyebabnya meningginya tingkat persaingan adalah perang harga serta inovasi produk baru dari kompetitor.
Secara umum dapat dikatakan bahwa semakin banyak jumlah kompetitor, semakin tinggi tingkat persaingan di dalam industri tersebut. Berikut ini merupakan pesaing dari Zalora yang merupakan pemain lama dalam bisnis online shop, yaitu:

(a) Kaskus,

(b) Lazada,

(c) Tokopedia,

(d) Dll.

Akan tetapi pesaing-pesaing tersebut tidak berfokus pada online shop fashion seperti yang dilakukan pada Zalora. Dengan demikian ancaman dari pesaing dalam industri online shop Zalora bisa dikatakan lemah, dikarenakan Zalora merupakan satu- satunya online shop yang berfokus pada fashion saja. Sehingga produk fashion yang terdapat pada Zalora sangatlah lengkap dibandingkan dengan online shop yang berfokus pada banyak bidang.

(2) Ancaman industri pendatang baru,

Banyaknya keuntungan yang didapat dari suatu bisnis akan dengan cepat menarik para pemain baru untuk terjun ke dalam persaingan. Pendatang baru pasti akan menambah tingkat kompetisi dalam suatu bisnis. Akan tetapi pendatang baru juga akan mendatangkan ancaman. Pendatang baru yang merupakan ancaman bagi Zalora adalah blibli.com dan mataharimall.com Kedua pendatang baru ini mungkin masih belum setenar pesaingnya. Kedua online shop ini memang berfokus pada fashion akan tetapi pendatang baru ini masih memiliki kekurangan yaitu produknya yang kurang begitu lengkap, mungkin karena iklan yang dilakukan masih belum sebanyak Zalora, sehingga para distributor atau pun pedagang juga belum begitu berminat untuk memasukkan dagangan ke 2 online shop ini. dengan demikian dapat dikatakan bahwaancaman industri pendatang baru untuk Zalora juga masih sangatlah Kuat. 
Akan tetapi Zalora masih bisa lebih unggul dibanding dengan industri pendatang baru tersebut.

(3) Ancaman produk pengganti yang mungkin menangkap mangsa pasar,

Semakin banyak barang atau layanan yang dapat menggantikan produk suatu perusahaan, maka posisi perusahaan tersebut semakin lemah. Bagi Zalora ancaman produk penggati antara lain:

(a) Pasar,

(b) Mall,

(c) Butik,

(d) Outlet atau Gerai,

(e) Dll

Sehingga dapat dikatakan bahwa ancaman produk pengganti yang mungkin menangkap mangsa pasar untuk Zalora masih sangatlah Kuat, ditandai dengan masih banyaknya produk pengganti untuk online shop Zalora.

(4) Kekuatan tawar pelanggan, dan

Ancaman kekuatan tawar pelanggan untuk ZaloraKuat. Dikarenakan harga produk di setiap online shop sangat kompetitif. Dan banyak disediakan program untuk menarik minat konsumen. Diantaranya pada blibli.com dan mataharimall.com terdapat fitur menarik yaitu bisa dicicil dengan bunga $0 \%$. Jadi dengan pembelian cash maupun cicil pembeli tetap mengeluarkan jumlah uang yang sama. Akan tetapi pada Zalora juga sangatlah banjir diskon dan voucher belanja. Pelanggan Zalora juga dapat menikmati kemudahan 30 hari gratis pengembalian, Pengiriman Gratis*, Pengiriman Tercepat selama 1-3 hari kerja dan beberapa metode pembayaran termasuk COD (Cash On Delivery).Sehingga dengan demikian kekuatan tawar pelanggan untuk Zalora masih sangatlah kuat, dengan ditandai dengan para pelanggan masih bisa beralih dengan mudah dari online shop satu ke online shop yang lainnya.
(5) Kekuatan tawar pemasok.

Perusahaan yang bergantung pada sedikit pemasokakan memiliki bargaining power yang lemah. Kelangkaan pemasok akan membuat mereka dengan mudah menaikkan harga bahan baku sehingga profit margin suatu perusahaan semakin menipis. Pada Zalora ini memiliki koleksi lebih dari 500 merek lokal, internasional dan designer, pelanggan dapat berbelanja online dengan pilihan produk fashion pria dan wanita mulai dari pakaian, sepatu, aksesoris dan produk kecantikan. Selain itu Zalora hanya satu-satunya online shop yang berfokus pada fashion. Sehingga kekuatan tawar pemasok untuk Zalora masih bisa dikatakan lemah. Karena seluruh pemasok pasti memasukan barang produksinya di Zalora ini.

b. Strategi Kompetitif

(1) Startegi Cost Leadership

Zalora menerapkan strategi Cost Leadership dengan senantiasa menyediakan banjir diskon dan voucher bagi para konsumennya. Diskon dan voucher ini terdapat diberbagai tempat. Antara lain:

(a) Voucher potongan harga $\mathrm{Rp}$. 75.000,00 untuk pelanggan baru,

(b) Diskon $15 \%$ untuk mendownload dan berbelanja di Zalora all item,

(2) Strategi Difensiasi

Zalora sebagai online shop masih terbilang sama dengan online shop lainnya. Hanya pada Zalora ini hanya berfokus pada penjualaan di bidang fashion saja. Sehingga dapat dikatakan Zalora tidak menerapkan strategi Diferensiasi pada Bisnisnya.

(3) Strategi Inovasi

Strategi Inovasi yang dilakukan Zalora lebih berpusat atau berfokus pada Website penjualannya yaitu pada Zalora.co.id dengan tersedianya fasilitas Live Chat yang dapat digunakan konsumen terkait dengan pertanyaan-pertanyaan yang ingin diajukan secara langsung (online) dengan 
Zalora. Selain itu website Zalora ini memiliki akses Help bagi para pengunjung yang menemukan kesulitan pada proses apapun. Sehingga pada saat para konsumen sedang mengaskses dan ingin berbelanja di Zalora akan sangat dipermudah dengan layanan ini.

(4) Strategi Pertumbuhan

Zalora dalam memperbesar kemampuan produksi, memperluas pasar dan diversifikasi produk baru masih sama dengan online shop lainnya yaitu dengan memiliki koleksi lebih dari 500 merek lokal, internasional dan designer, pelanggan dapat berbelanja online dengan pilihan produk fashion pria dan wanita mulai dari pakaian, sepatu, aksesoris dan produk kecantikan. Sehingga dapat dikatakan bahwa Zalora tidak menggunakan Strategi Pertumbuhan.

(5) Strategi Aliansi

Zalora menggunakan strategi aliansi untuk mengembangkan bisnisnya. Yaitu dengan menyediakan program Brand Ambasador Program (BAP) adalah program afiliasi individual yang diperuntukan untu konsumen yang smart dan fashionable untuk memenuhi beragam kebutuhan konsumen. Dengan bergabung pada program ini, konsumen akan mendapatkan berbagai manfaat dan keuntungan yang tidak akan didapat di tempat lain. Manfaat yang didapatkan konsumen antara lain: kesempatan berpenghasilan jutaan rupiah, dapat berbelanja produk fashion yang berkualitas tanpa membayar., menjadi fashion icon, menjadi yang pertama mengetahui penawaran terbaik dari Zalora.

\section{SIMPULAN}

1) Sistem Informasi Zalora ini dianalisi menggunakan metode Competitive Force and Competitive Strategy.

2) Pada Variabel yang terdapat di Competitive Forcedidapatkan hasil bahwa
Sistem Informasi Zalora ini lemah dalam menghadapi Ancaman Kekuatan tawar pelanggan, Ancaman produk pengganti yang mungkin menangkap mangsa pasar, Ancaman industri pendatang baru. Dikarena banyaknya online shop yang bermunculan saat ini. sehingga ini termasuk kelemahan dari Sistem Informasi Zalora.

3) Akan tetapi Sistem Informasi Zalora ini juga kuat dalam menghadapi Ancaman Persaingan dari pesaing dalam industri dan Ancaman Kekuatan tawar pemasok. karena Zalora merupakan satu-satunya online shop yang berfokus pada fashion. Sehingga ini termasuk dalam kelebihan dari Sistem Informasi Zalora.

4) Untuk mengadapi Competitive Force yang timbul, maka Zalora menggunakan beberapa Competitive Strategy. Sehingga kelebihan dari Sistem Informasi Zalora terletak pada Strategi Cost Leadership, Strategi Inovasi, dan Strategi Aliansi.

\section{DAFTAR RUJUKAN}

http://ardiantareza.blogspot.co.id/2014/05/a nalisis-dari-e-commercezaloracoid.html diakses pada tanggal 15 April 2016.

https://kikisaragih.wordpress.com/2009/01/ 14/five-forces-model-porter/ diakses pada tanggal 15 April 2016

https://id.wikipedia.org/wiki/Analisis_lima _kekuatan_Porter diakses pada tanggal 15 April 2016

O'Brien, James A, (2009). Introdaction to Information Systems. United States: McGraw-Hil 
http://hamtox.blogspot.co.id/2013/07/makal

ah-e-business-dan-e-commerce.html

diakses pada tanggal 15 April 2016

http://www.nurulfikri.ac.id/index.php/artike 1/item/667-kelebihan-dan-

kekurangan-e-commerce diakses pada tanggal 15 April 2016

Turban, E. dan King D. 2002. Electronic Commerce 2002: A Managerial Perspective (2nd Edition). London: Prentice Hall 